MEDICINE AND THE LAW

\title{
The Teddy Bear Clinic Constitutional Court case: Sexual conduct between adolescent consenting children aged under 16 years decriminalised and a moratorium on the reporting duties of doctors and others
}

\author{
D J McQuoid-Mason \\ David McQuoid-Mason is Professor of Law at the Centre for Socio-Legal Studies, University of KwaZulu-Natal, Durban, South Africa, and publishes \\ and teaches in medical law.
}

Corresponding author: D J McQuoid-Mason (mcquoidm@ukzn.ac.za)

The Constitutional Court in the Teddy Bear Clinic appeal case held that the sections of the Sexual Offences Act that impose criminal liability for sexual offences on adolescent children under 16 years of age are invalid. The invalidity was suspended for 18 months to allow Parliament to correct the Act's defects. A moratorium was imposed on all investigations into, arrests in, prosecutions in, and criminal and ancillary proceedings regarding such section 15 and 16 offences. This includes the duty to report consensual sexual conduct between children under 16 years of age in terms of section 54 of the Act - pending Parliament's correction. However, it is submitted that the 'best interests of the child' principle in the Children's Act and the Constitution should guide all obligatory reporting situations involving sexual and other conduct of children, irrespective of whether they are adolescents under 16 years old or between 16 and 17 years old.

S Afr Med J 2014;104(4):275-276. DOI:10.7196/SAMJ.7653

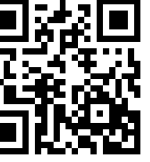

In The Teddy Bear Clinic appeal case, ${ }^{[1]}$ the Constitutional Court held: (i) sections 15 and 16 of the Sexual Offences Act are invalid, where they impose criminal liability for sexual offences on adolescent children aged under 16 years; (ii) the invalidity is suspended for 18 months to allow Parliament to correct the Act's defects; (iii) a moratorium is imposed on all investigations into, arrests in, prosecutions in, and criminal and ancillary proceedings regarding such section 15 and 16 offences - including the duty to report such consensual sexual conduct between children aged under 16 years in terms of section 54 of the Act ${ }^{[1]}$ - pending Parliament's corrections; and (iv) convictions or diversion orders made because of such offences committed by children aged under 16 years in terms of these sections of the Act must be expunged from the criminal record register and the National Register for Sexual Offenders.

\section{Declaration of invalidity of sections 15} and 16 of the Sexual Offences Act

The court found that the parts of sections 15 and 16 of the Act that criminalised consensual sexual penetration or sexual violation between adolescent children under the age of 16 years violated the constitutional rights to dignity and privacy and the 'best interests of the child' provisions of the Constitution, and could not be saved by the limitation clause. ${ }^{[2]}$

Sections 15 and 16 violate the dignity of such children because they punish 'forms of sexual expression that are developmentally normal', which 'degrades and inflicts a state of disgrace on adolescents. Convicted adolescents are also stigmatised by having their names placed in the National Register for Sexual Offenders. ${ }^{[1]}$

Parts of these sections infringe the right to privacy of adolescents under 16 years of age because they allow 'police officers, prosecutors and judicial officers to scrutinise and assume control of their intimate relationships, thereby intruding into a deeply personal realm of their lives. ${ }^{[1]}$ Furthermore, the relationship is undermined between adolescents and 'trusted third parties' (such as doctors and social workers) who 'are obliged to disclose information which may have been shared with them in the strictest confidence, on pain of prosecution. $^{\text {'1] }}$

The 'best interests of the child' principle in the Constitution ${ }^{[2]}$ is violated because the offences created in the sections 'exacerbate harm and risk to adolescents by undermining support structures, preventing adolescents from seeking help and potentially driving their sexual behaviour underground. ${ }^{[1]}$ They 'create a rupture of family life and invite a breakdown of parental care by severing the lines of communication between parent or guardian and child?. ${ }^{[1]}$ Criminal liability could 'at worst lead to imprisonment, and, at best, lead to diversion procedures'. In the latter case the adolescent 'may still be arrested and forced to interact with arresting and investigating police officials' and 'acknowledge "responsibility for the offence" to a magistrate' before diversion can take place. ${ }^{[1]}$ The adolescent would also be forced to 'disclose and have scrutinised details of his or her intimate affairs. ${ }^{[1]}$ The alleged safeguard of 'prosecutorial discretion' does not exist, because before it can be exercised such information must be provided. ${ }^{[1]}$ The court concluded that it was 'fundamentally irrational to state that adolescents do not have the capacity to make choices about their sexual activity, yet in the same breath to contend that they have the capacity to be held criminally liable for such choices. ${ }^{[1]}$

Sections 15 and 16 were not saved by the limitation clause of the Constitution $^{[2]}$ 'because there was no evidence that criminalising such consensual sexual behaviour would deter adolescents from engaging in it. ${ }^{[1]}$ On the contrary, the court accepted the evidence that the 
sections cause 'caregivers and institutions [to be] disempowered in dealing with adolescents because ... in the course of attempting to provide guidance and assistance, they may well be told intimate information which they will be obliged to report to the authorities. ${ }^{[1]}$ The court also doubted whether the prohibitions in the sections could 'ever be shown to be a constitutionally sound means of preventing the occurrence of such risks as teenage pregnancy, ${ }^{[1]}$ as the state's lawyers contended. The court therefore confirmed the declaration of constitutional invalidity by the North Gauteng High Court, ${ }^{[1,3]}$ of the parts of sections 15 and 16 affecting consensual sexual conduct by adolescent children under 16 years of age.

Invalidity suspended for 18 months to allow Parliament to correct the defects The Constitutional Court did not accept the North Gauteng High Court's decision to sever parts of sections 15 and 16 and to read in other parts. Firstly, this was because the impugned provisions serve an important function insofar as they impose criminal liability on an adult for engaging in sexual conduct with a consenting adolescent', which is not provided for elsewhere in the Act and must be preserved. ${ }^{[1]}$ Secondly, because the sections are interlinked with other provisions in the Act, 'severing portions from, and reading words into, those sections might therefore have unintended consequences' and 'holistic revision by Parliament would be more appropriate to address the concerns' in the judgment. ${ }^{[1]}$ The court also mentioned that Parliament may wish 'to reconsider the close-in-age' defence and whether it should be applied to sexual penetration as advocated by the applicants in the case, ${ }^{[1]}$ as also suggested elsewhere. ${ }^{[4]}$ In addition, Parliament 'may wish to regulate "sexual penetration" between an adolescent and a minor aged 16 or 17 in a manner different to that proposed by the applicants. ${ }^{[1]}$ Therefore, although parts of sections 15 and 16 were declared invalid, 'justice and equity warrant that their invalidity should be suspended for a period of 18 months in order to allow Parliament to remedy the defects in the statute.[1]

\section{Moratorium on criminal and ancillary proceedings regarding section 15 and 16 offences}

The court ordered a moratorium on all investigations into, arrests in, prosecutions in, and criminal and ancillary proceedings regarding section 15 and 16 offences involving consensual sexual conduct between adolescent children under 16 years of age. The moratorium on the duty to report consensual sexual conduct between children under 16 years of age was not specifically mentioned, ${ }^{[1]}$ but the court's language earlier makes it clear that 'ancillary proceedings' include the duty to report such conduct - pending Parliament's correction of the Act. ${ }^{[1}$

Doctors and other health professionals therefore have no duty to report consensual sexual conduct between adolescent children under 16 years of age. Although the declaration of the invalidity of the relevant parts of sections 15 and 16 was suspended, the court did not impose a moratorium on criminal liability for sexual conduct by children aged 16 or 17 years. It is submitted, however, that in such instances the 'best interests of the child' principles in the Children's $\mathrm{Act}^{[5]}$ and the Constitution should apply, as the latter is paramount. ${ }^{[2]}$ Guidance regarding the factors that should be taken into account when determining the 'best interests of the child' are set out in the Children's Act. ${ }^{[5]}$

Therefore, whether children facing criminal liability for sexual conduct are under or over 16 years of age, doctors and other healthcare practitioners should be guided by the "best interests of the child' principle when it comes to reporting such conduct. For instance, even if both the adolescents are under 16 years of age it may still constitute child abuse if one of them is in a position of power or control over the other. Such sexual conduct cannot be regarded as 'consensual' and must be reported.

\section{Expunging of criminal and diversion records of adolescent children}

The Constitutional Court ordered the Minister of Justice and Constitutional Development to have the criminal records or diversion orders of any adolescents under 16 years of age expunged as a result of sections 15 or 16 of the Sexual Offences Act, and their details to be removed from the National Register for Sexual Offenders. ${ }^{[6]}$

\section{Conclusion}

The following conclusions can be drawn from the Constitutional Court's decisions:

- The findings of invalidity of sections 15 and 16 of the Sexual Offences Act are limited to those that criminalise sexual conduct of adolescent children under 16 years of age. ${ }^{[2}$

- Doctors and other health professionals no longer need to report consensual sexual conduct of adolescent children under 16 years of age to the authorities in terms of the Sexual Offences Act. ${ }^{[2]}$

- Criminalisation of non-consensual sexual conduct is not affected, 'including cases of undue influence or other instances where consent has not properly been given', or the criminalisation of sexual conduct between adults and children or between adolescents and children older than 16 years. ${ }^{[1]}$

- The court had insufficient evidence to decide that sections 15 and 16 of the Sexual Offences Act 'have the same constitutional implications for 16 and 17 year olds as they do for adolescents', and was not prepared to read in a 'close-in-age' defence or confirm the Gauteng High Court's judgment in this respect. ${ }^{11}$

- The decision only applies to the reporting obligations of doctors and others regarding the sexual conduct of adolescent children under 16 years of age in terms of the Sexual Offences Act. ${ }^{[1,6]}$

However, it is submitted that the 'best interests of the child' principle in the Children's Act ${ }^{[5]}$ and the Constitution ${ }^{[2]}$ should guide all obligatory reporting situations involving sexual and other conduct of children - irrespective of whether they are adolescents under 16 years or between 16 and 17 years of age. ${ }^{[4]}$

\footnotetext{
1. The Teddy Bear Clinic for Abused Children Case and RAPCAN and Others v. Minister of Justice and National Director of Public Prosecutions CCT 12/13 [2013] ZACC (3 October 2013). http://www. saflii.org/za/cases/ZACC/2013/35html (accessed 14 October 2013)

2. South African National Government. The Constitution of the Republic of South Africa 1996 Pretoria: Government Printer, 1996: http://www.thehda.co.za/uploads/images/unpan005172.pd (accessed 14 October 2013)

3. McQuoid-Mason D. Decriminalization of consensual sexual conduct between children: What should doctors do regarding the reporting of sexual offences under the Sexual Offences Act until the Constitutional Court confirms the judgment of the Teddy Bear Clinic case? South African Journa of Bioethics and Law 2013;6(1):10-12.

4. McQuoid-Mason D. Mandatory reporting of sexual abuse under the Sexual Offences Act and the best interests of the child. South African Journal of Bioethics and Law 2011;4(2):74-78

5. South African National Government. The Children's Act No. 38 of 2005. Pretoria: Government Printer, 2005. http://www.justice.gov.za/legislation/acts/2005-038\%20childrensact.pdf (accessed 14 October 2013).

6. South African National Government. Criminal Law (Sexual Offences and Related Matters) Amendment Act 32 of 2007. Pretoria: Government Printer, 2007. http://www.justice.gov.za/ legislation/acts/2007-032.pdf (accessed 14 October 2013)
}

Accepted 7 November 2013. 